\title{
Endotoxin levels and contribution factors of endotoxins in resident, school, and office environments - A review
}

\section{Salonen, Heidi}

2016-10

Salonen, H, Duchaine , C, Letourneau , V , Mazaheri , M, Laitinen , S, Clifford , S , Mikkola , R , Lappalainen, S , Reijula , K \& Morawska , L 2016 , ' Endotoxin levels and contribution factors of endotoxins in resident, school, and office environments - A review ' , Atmospheric Environment, vol. 142 , pp. 360-369 . https://doi.org/10.1016/j.atmosenv.2016.08.018

http://hdl.handle.net/10138/225835

https://doi.org/10.1016/j.atmosenv.2016.08.018

publishedVersion

Downloaded from Helda, University of Helsinki institutional repository.

This is an electronic reprint of the original article.

This reprint may differ from the original in pagination and typographic detail.

Please cite the original version. 
Review article

\title{
Endotoxin levels and contribution factors of endotoxins in resident, school, and office environments - A review
}

\author{
Heidi Salonen ${ }^{a,}$, Caroline Duchaine ${ }^{\mathrm{b}, \mathrm{c}}$, Valérie Létourneau ${ }^{\mathrm{c}}$, Mandana Mazaheri ${ }^{\mathrm{d}}$, \\ Sirpa Laitinen ${ }^{\text {e, Sam Clifford }}{ }^{\mathrm{d}, \mathrm{f}}$, Raimo Mikkola ${ }^{\mathrm{a}}$, Sanna Lappalainen ${ }^{\mathrm{g}}$, Kari Reijula ${ }^{\mathrm{h}}$, \\ Lidia Morawska ${ }^{\mathrm{d}}$
}

a Aalto University, Department of Civil and Structural Engineering, PO Box 12100, FI-00076, Aalto, Finland

${ }^{\mathrm{b}}$ Université Laval, Département de Biochimie, de Microbiologie et de Bio-informatique, 2325, rue de l'Université Québec G1V 0A6, Canada

' Centre de recherche de l'Institut universitaire de cardiologie et de pneumologie de Québec, 2725, chemin Sainte-Foy, Québec G1V 4G5, Canada

${ }^{\mathrm{d}}$ Queensland University of Technology, International Laboratory for Air Quality and Health, 2 George Street, Brisbane, Q 4001, Australia

e Finnish Institute of Occupational Health, Biological Hazards and Indoor Air, Neulaniementie 4, FI-70101, Kuopio, Finland

${ }^{\mathrm{f}}$ Centre for Air Quality \& Health Research and Evaluation, 431 Glebe Point Rd, Glebe, 2037, Australia

${ }^{\mathrm{g}}$ Finnish Institute of Occupational Health, Developing Indoor Environments, Topeliuksenkatu 41 aA, FI-00250, Helsinki, Finland

${ }^{\text {h } H e l s i n k i ~ U n i v e r s i t y, ~ C l i n i c u m, ~ D e p a r t m e n t ~ o f ~ P u b l i c ~ H e a l t h, ~ T u k h o l m a n k a t u ~ 8, ~ F I-00014, ~ F i n l a n d ~}$

\section{H I G H L I G H T S}

- Mean endotoxin loads in settled floor dust were $660-107,000 \mathrm{EU} / \mathrm{m}^{2}$.

- Mean airborne endotoxin concentrations in indoor air were $0.04-1610 \mathrm{EU} / \mathrm{m}^{3}$.

- There were several strong determinants for the endotoxin loads.

- The presence of pets was extremely strong determinant for the endotoxin concentration.

- Literature findings concerning several determinants were inconsistent.

\section{A R T I C L E I N F O}

\section{Article history:}

Received 16 February 2016

Received in revised form

2 August 2016

Accepted 6 August 2016

Available online 6 August 2016

\section{Keywords:}

Endotoxins

Indoor environments

Environmental characteristics

Airborne endotoxins

Bioaerosols

Settled dust

\begin{abstract}
A B S T R A C T
As endotoxin exposure has known effects on human health, it is important to know the generally existing levels of endotoxins as well as their contributing factors. This work reviews current knowledge on the endotoxin loads in settled floor dust, concentrations of endotoxins in indoor air, and different environmental factors potentially affecting endotoxin levels. The literature review consists of peer-reviewed manuscripts located using Google and PubMed, with search terms based on individual words and combinations. References from relevant articles have also been searched. Analysis of the data showed that in residential, school, and office environments, the mean endotoxin loads in settled floor dust varied between 660 and $107,000 \mathrm{EU} / \mathrm{m}^{2}, 2180$ and 48,000 EU/m $/ \mathrm{m}^{2}$, and 2700 and 12,890 EU/m², respectively. Correspondingly, the mean endotoxin concentrations in indoor air varied between 0.04 and $1610 \mathrm{EU} / \mathrm{m}^{3}$ in residences, and 0.07 and $9.30 \mathrm{EU} / \mathrm{m}^{3}$ in schools and offices. There is strong scientific evidence indicating that age of houses (or housing unit year category), cleaning, farm or rural living, flooring materials (the presence of carpets), number of occupants, the presence of dogs or cats indoors, and relative humidity affect endotoxin loads in settled floor dust. The presence of pets (especially dogs) was extremely strongly associated with endotoxin concentrations in indoor air. However, as reviewed articles show inconsistency, additional studies on these and other possible predicting factors are needed.
\end{abstract}

(C) 2016 Elsevier Ltd. All rights reserved.

\footnotetext{
* Corresponding author.

E-mail address: heidi.salonen@aalto.fi (H. Salonen).
}

\section{Introduction}

There is great concern about the potential health hazard of biological components in airborne particulate matter (bioaerosols), 
including endotoxins, in indoor environments. Endotoxin is a biologically active lipopolysaccharide that is a component of the outer membrane of gram-negative bacteria (Duchaine et al., 2001; Rennie et al., 2012; Todar, 2015) and has been shown to cause health responses among occupants. Epidemiologic and toxicologic studies provide evidence associating elevated endotoxin levels with increased asthma severity and bronchial hyperresponsiveness (Rabinovitch et al., 2005; Thorne et al., 2005), and it has been reported recently in a review study (Kanchongkittiphon et al., 2015) that there is sufficient evidence of an association between indoor endotoxin exposure and exacerbation of asthma. Although some studies have suggested a protective role of endotoxin exposure in infancy (Liu, 2002) or at school age (Norbäck et al., 2014), exposure to endotoxins later in life appears to have a detrimental effect in both individuals with asthma and other respiratory conditions and in healthy volunteers (Michel et al., 1996; Gehring et al., 2001; Thorne et al., 2009). Thus, to reduce endotoxin exposure may be important for the control of detrimental effects, and examine the association between indoor characteristics and endotoxin levels is prerequisite in reducing.

Although several studies were carried out worldwide to assess indoor exposure to endotoxins mainly through quantification of endotoxin loads in settled dust samples collected by vacuum cleaners (Noss et al., 2008; Samadi et al., 2010; Frankel et al., 2012b), and a few studies were conducted to measure endotoxin levels in ambient air (Park et al., 2000; Heinrich et al., 2003; Morgenstern et al., 2005; Dales et al., 2006; Wheeler et al., 2011), an overall overview of the data about the loads and concentration of endotoxin in different indoor environments is not available. Duquenne et al. (2013) reviewed examples of the airborne inhalable endotoxin concentration levels measured at the workplace but not in other indoor environments, such as residences. In addition, despite the reported sources and predictors of endotoxin - such as dairy farming, pets, cigarette smoke and dampness (Park et al., 2001a; Bischof et al., 2002; Tavernier et al., 2005; Mazique et al., 2011; Bari et al., 2014) - a systematic summary of the different predictors of endotoxin loads in indoor settled dust and endotoxin concentrations in indoor air is needed. Moreover, there is a need to rank the different predictors in indoor settings in terms of their importance.

With this motivation in mind, the aim of the present review study was (1) to summarize the reported endotoxin loads in settled floor dust (expressed as $\mathrm{EU} / \mathrm{m}^{2}$ ) and airborne endotoxin concentrations (expressed as $\mathrm{EU} / \mathrm{m}^{3}$ ) in school, office and residential indoor environments; (2) to summarize the different predictors of endotoxin in settled dust and indoor air; and (3) to rank the predictors of endotoxin in terms of their importance.

\section{Material and methods}

\subsection{Literature search and selection}

A PubMed search of the literature published between 1958 and 2016 was performed at http://www.ncbi.nlm.nih.gov/pubmed/ (National Library of Medicine (NLM), a division of the National Library of Medicine (NLM) at the National Institutes of Health (NIH)). Altogether, 52 search terms (See Table S1 in supplementary material $(\mathrm{SM})$ ) as well as different combinations of those terms were used. Searches included combinations of at least three terms simultaneously, and the terms endotoxin and indoor air/floor dust were used each time. Original peer-reviewed scientific articles and literature reviews were included in the search. Then, a search was done in the lists of references of relevant articles (based on their title and abstract) that included measurements of endotoxins in settled floor dust (expressed as $\mathrm{EU} / \mathrm{m}^{2}$ ) and/or in the air (expressed as the $\mathrm{EU} / \mathrm{m}^{3}$ ) as well as environmental factors affecting the levels of endotoxins. From the lists of references, relevant articles (based on their titles) were chosen for a detailed search. A few often-cited authors (Park, Chen, Gehring, and Thorne) were also added as search terms. Personal contacts with experts in the field were also established in order to collect relevant data. The basic search was performed from April 2013 to February 2014 and updated from September 2015 to July 2016.

A total of 290 abstracts were selected based on the eligibility of their titles, 200 of which were read based on the eligibility of their abstracts. Review of the whole articles was subject to their availability in the electronic databases of Aalto University, QUT (Queensland University of Technology), FIOH (Finnish Institute of Occupational Health) library subscriptions, or as free downloads from the Internet.

In the next step, 122 publications were selected for inclusion in the analysis. Indoor environments in this work include residential, school, and office buildings.

\subsection{Relationship between environmental factors and the endotoxin} loads in settled dust and the concentrations of airborne endotoxins

The relationship between environmental factors and the endotoxin loads in settled dust and the concentrations of airborne endotoxins were classified into three categories: 1) Extremely strong scientific evidence (several $(\geq 6)$ empirical studies from peerreviewed journals and/or several systematic reviews, as reviewed herein); 2) Strong scientific evidence (at least three empirical studies from peer-reviewed journals and/or at least three systematic reviews, as reviewed herein); and 3) Scientific evidence was found (one or two empirical studies from peer-reviewed journals).

\section{Results and discussion}

\subsection{Endotoxin loads in settled surface floor dust in different indoor environments}

We found 11 residential studies from 3160 residents $(n=9049)$, three school studies $(\mathrm{n}=95)$ from 42 school buildings and two office studies $(n=630)$ from two offices that reported the loads of endotoxins in settled floor dust expressed as $\mathrm{EU} / \mathrm{m}^{2}$. A summary of these studies is presented in Table 1 and detailed information of studies is available in Table S2 in the SM. In all of the selected studies settled floor dust samples were collected by using vacuum cleaners. In all the studies, endotoxins were evaluated with a LAL based bioassay (e.g. kinetic turbidimetric LAL, endpoint chromogenic LAL or kinetic chromogenic LAL) (Chun et al., 2002; Thorne et al., 2009). Other detailed information about the selected studies is presented in Table S2 in the SM.

In a residential settings, the reported average loads of endotoxin in the floor dust collected by vacuum cleaners varied between 660 $\mathrm{EU} / \mathrm{m}^{2}$ (in the Netherlands) and $107,000 \mathrm{EU} / \mathrm{m}^{2}$ (in Cincinnati and Northern Kentucky, USA) (Douwes et al., 1998; Wouters et al., 2000; Gehring et al., 2002; Wickens et al., 2003b; Thorne et al., 2005; Perzanowski et al., 2006; Gehring et al., 2008; Noss et al., 2008; Thorne et al., 2009; Johansson et al., 2013; Adhikari et al., 2014; Holst et al., 2015a). In a study comparing farming and nonfarming households, the endotoxin loads in settled floor dust were higher in farming households (geometric mean [GM]: $28,400-29,900 \mathrm{EU} / \mathrm{m}^{2}$ ) than in non-farming households (GM: 11,500-14,460 EU/m²) (Noss et al., 2008).

In a school environment, mean (GM) endotoxin loads in the settled floor dust collected by vacuum cleaners varied between 2200 and 48,000 EU/m² (Foarde and Berry, 2004; Ebbehøj et al., 2005; Salonen et al., 2013; Holst et al., 2015a). The lowest and 
Table 1

The loads of endotoxin $\left(\mathrm{EU} / \mathrm{m}^{2}\right)$ in the settled floor dust of different indoor environments.

\begin{tabular}{|c|c|c|c|}
\hline $\begin{array}{l}\text { Study location } \\
\text { Type of buildings (number of buildings) }\end{array}$ & Dust sampling location & $\mathrm{n}^{*}$ & Endotoxin $\left(\mathrm{EU} / \mathrm{m}^{2}\right)$ \\
\hline $\begin{array}{l}\text { Residential studies } \\
\text { Albania, Italy, New Zealand, } \\
\text { Sweden, UK) } \\
\text { Homes (840) } \\
\text { (Gehring et al., 2008) }\end{array}$ & Living-room floor dust & 840 & Range GM: 684 (Rome) - 3602 (Östersund) \\
\hline Cincinnati and Kentucky & Home floor dust (low-ERMI-homes) & 31 & GM: 107,000 \\
\hline $\begin{array}{l}\text { Low (31) and high (11) ERMI-homes } \\
\text { (Adhikari et al., 2014) }\end{array}$ & Home floor dust (high-ERMI-homes) & 11 & GM: 84,000 \\
\hline Cincinnati, USA & Home floor dust from the child's (with and & 158 & GM: 62,700 (GSD: 5.1) \\
\hline Homes (158) & without asthma) primary activity room & 32 & GM: 62,900 (GSD: 5.5$)$ \\
\hline (Johansson et al., 2013) & $\begin{array}{l}\text { Home floor dust from the child's (with asthma) } \\
\text { primary activity room } \\
\text { Home floor dust from the child's (without } \\
\text { asthma) primary activity room }\end{array}$ & 126 & GM: 65,000 (GSD: 5.1 ) \\
\hline $\begin{array}{l}\text { Denmark } \\
\text { Homes (317) } \\
\text { (Holst et al., 2015a) }\end{array}$ & Bedroom floor dust & 317 & GM: 5460 (GSD 8000) \\
\hline $\begin{array}{l}\text { East Harlem, the South Bronx, Washington } \\
\text { Heights and West Harlem, New York, NY, } \\
\text { USA }\end{array}$ & Home floor dust & 5704 & GM: 3892; Range: 3351-4522 \\
\hline $\begin{array}{l}\text { Inner-city homes (301) } \\
\text { (Perzanowski et al., 2006) }\end{array}$ & & & \\
\hline Germany & House floor dust & 50 & Range: $700-32,900$ \\
\hline $\begin{array}{l}\text { City homes (25) } \\
\text { (Douwes et al., 1998) }\end{array}$ & Bedroom floor dust & 25 & GM: 7400 (GSD 2.5) \\
\hline Netherlands & Living-room dust (farm homes) & 36 & GM: 28,400 (GSD: 4.49) \\
\hline $\begin{array}{l}\text { Farm (9) and non-farm (7) homes } \\
\text { (Noss et al., 2008) }\end{array}$ & Living-room dust (non-farm homes) & 28 & GM: 11,500 (GSD: 4.98) \\
\hline Netherlands & Living-room floor dust (with organic waste bin) & 51 & GM: 950 (GSD: 8.4) \\
\hline Households (99) & Kitchen floor dust (no organic waste bin) & 48 & GM: 2443 (GSD: 6.6) \\
\hline (Wouters et al., 2000) & Kitchen floor dust (with organic waste bin) & $\begin{array}{l}49 \\
48\end{array}$ & $\begin{array}{l}\text { GM: } 662 \text { (GSD: 6.6) } \\
\text { GM: } 2276 \text { (GSD: } 8.5)\end{array}$ \\
\hline $\begin{array}{l}\text { Saxony-Anhalt, Germany } \\
\text { Houses (454) } \\
\text { (Gehring et al., 2002) }\end{array}$ & Living-room floor dust & 454 & GM: 24,221 (GSD: 4.1) \\
\hline United States & Bedroom floor dust & 585 & GM:10,500 (GSE: 1.09) \\
\hline $\begin{array}{l}\text { Houses (831) } \\
\text { (Thorne et al., 2005; Thorne et al., 2009) }\end{array}$ & Family room floor dust & 488 & GM: 17,600 (GSE: 1.08$)$ \\
\hline Wellington, New Zealand & Floor dust from a $1 \mathrm{~m}^{2}$ area & 77 & GM: 30,544 (GSD: 3.2) \\
\hline $\begin{array}{l}\text { Suburban houses (77) } \\
\text { (Wickens et al., 2003b) } \\
\text { School studies }\end{array}$ & Floor dust from the whole room area & 74 & GM: 5653 (GSD: 6.4) \\
\hline $\begin{array}{l}\text { Australia } \\
\text { Schools (25) } \\
\text { (Salonen et al., 2013) }\end{array}$ & Dust from a carpeted floor & 44 & GM: 7502 (STDEV: 6563) \\
\hline $\begin{array}{l}\text { Danish municipalities } \\
\text { Schools (15) } \\
\text { (Ebbehøj et al., 2005; Holst et al., 2015a) }\end{array}$ & Floor dust & 21 & GM: 2400 (GSD: 3190) \\
\hline North Carolina & Dust from a carpeted floor & 15 & GM: 48,000 (GSD: 3.4$)$ \\
\hline $\begin{array}{l}\text { Rural schools (2) } \\
\text { (Foarde and Berry, 2004) } \\
\text { Office studies }\end{array}$ & Dust from a tiled floor & 15 & GM: 2200 (GSD: 2.8) \\
\hline $\begin{array}{l}\text { Metropolitan area in the north-east United } \\
\text { States } \\
\text { Office (1) } \\
\text { (Park et al., 2006) }\end{array}$ & Workstation dust from a carpeted floor & 333 & GM: 2700 (GSD: 4.8) \\
\hline $\begin{array}{l}\text { Metropolitan area in the north-east United } \\
\text { States } \\
\text { Office (1) } \\
\text { (Akpinar-Elci et al., 2013) }\end{array}$ & $\begin{array}{l}\text { Workstation floor dust (after extensive } \\
\text { remediation work due to water damages) }\end{array}$ & 297 & GM: 12,891 (GSD: 5.7) \\
\hline
\end{tabular}

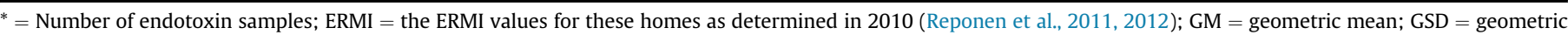
standard deviation; GSE = geometric standard error; NR = not reported.

highest mean values were reported in rural schools in North Carolina. In an office environment, mean (GM) endotoxin loads in settled floor dust varied between 2700 and $12,890 \mathrm{EU} / \mathrm{m}^{2}$ in a metropolitan area in the north-east of the United States (Park et al., 2006; Akpinar-Elci et al., 2013).

\subsection{Endotoxin concentrations in indoor air of different indoor environments}

Table 2 shows the airborne endotoxin concentrations from 34 published studies on residential microenvironments (1970 residents, 3521 samples), school microenvironments (59 schools, 123 samples) and an office microenvironment (one office, two 
Table 2

The concentrations of airborne endotoxins in different indoor environments.

\begin{tabular}{|c|c|c|c|}
\hline $\begin{array}{l}\text { Study location } \\
\text { Type of buildings (number of buildings) }\end{array}$ & $\begin{array}{l}\text { Sampling location/housing and other } \\
\text { characteristics }\end{array}$ & $\mathrm{n}^{*}$ & Endotoxin $\left(\mathrm{EU} / \mathrm{m}^{3}\right)$ \\
\hline \multicolumn{4}{|l|}{ Residential studies } \\
\hline $\begin{array}{l}\text { Baltimore, MD, Maryland, USA. } \\
\text { Homes (84) } \\
\text { (Hansel et al., 2013; Bose et al., 2015) }\end{array}$ & Participant's main living area & 84 & AM: 0.55 (SD: 1.3) \\
\hline $\begin{array}{l}\text { Baltimore, MD, Maryland, USA. } \\
\text { Inner-city homes (85) } \\
\text { (Mazique et al., 2011) }\end{array}$ & Bedroom & 170 & AM: 0.13 (SD: 0.26) \\
\hline Bavaria and Switzerland & Inhalable (PM7.5) endotoxins from several & 30 & GM:150 \\
\hline $\begin{array}{l}\text { Farming homes (30) } \\
\text { (von Mutius et al., 2000) }\end{array}$ & $\begin{array}{l}\text { locations where children were usually playing } \\
\text { Respirable (PM2.5) endotoxins from several } \\
\text { locations where children were usually playing }\end{array}$ & 30 & GM: 7 \\
\hline $\begin{array}{l}\text { Boston, Massachusetts, USA } \\
\text { Metropolitan homes ( } 82 \text { ) } \\
\text { (Horick et al., 2006) }\end{array}$ & Living room & 404 & AM: 0.81 \\
\hline $\begin{array}{l}\text { Boston, Massachusetts, USA } \\
\text { Homes (15) } \\
\text { (Park et al., 2000) }\end{array}$ & Bedroom & 142 & GM: 0.64 (GSD: 2.6) \\
\hline $\begin{array}{l}\text { Boston, Massachusetts, USA } \\
\text { Homes (116) } \\
\text { (Park et al., 2001b) }\end{array}$ & Family room & 116 & GM: 0.77 (GSD: 2.3) \\
\hline Boulder, Colorado, USA & Kitchen/living room during weekday and & 30 & Weekday: AM: 0.052 \\
\hline $\begin{array}{l}\text { Homes (30) } \\
\text { (Escobedo et al., 2014) }\end{array}$ & weekend & & Weekend: AM: 0.058 \\
\hline $\begin{array}{l}\text { Brussel, Belgium Naturally ventilated homes (9) } \\
\text { (Bouillard et al., 2006) }\end{array}$ & $\begin{array}{l}\text { Naturally ventilated rooms, inhalable and } \\
\text { respirable endotoxins }\end{array}$ & 18 & Range: $0.0025-12.147$ \\
\hline Cincinnati and Northern Kentucky, USA & Low-ERMI homes & 31 & GM: 4.44 \\
\hline $\begin{array}{l}\text { Low (31) and high (11) ERMI homes } \\
\text { (Adhikari et al., 2014) }\end{array}$ & High-ERMI-homes & 11 & GM: 8.64 \\
\hline $\begin{array}{l}\text { Cincinnati and Northern Kentucky, USA } \\
\text { Homes (184) } \\
\text { (Reponen et al., 2010) }\end{array}$ & Children's primary activity room & 184 & GM: 4.2 \\
\hline Danmark & Homes during spring & 19 & Median: 1.24; Range: 0.078-8.32 Median:1.48; \\
\hline Homes (5) & Homes during summer & 11 & Range: $0.32-3.38$ \\
\hline (Frankel et al., 2012a) & Homes during autumn & 10 & Median: 0.88; Range: 0.59-4.59 \\
\hline & Homes during winter & 12 & Median: 0.86; Range: $0.21-2.56$ \\
\hline Edmonton, Canada & Winter sample from a family room or living & 142 & Median: 0.12; Range: $0.002-12$ \\
\hline $\begin{array}{l}\text { Homes with no reported smoking (76) } \\
\text { (Bari et al., 2014) }\end{array}$ & $\begin{array}{l}\text { room ( } 26 \text { homes) } \\
\text { Summer sample from a family room or living } \\
\text { room ( } 50 \text { homes) }\end{array}$ & 243 & Median: 0.41; Range: 0.005-53 \\
\hline $\begin{array}{l}\text { Fresno, California, USA } \\
\text { Homes (83) } \\
\text { (Tager et al., 2010) }\end{array}$ & Homes measured during different months & 83 & Range GM: $0.28-3.77$ \\
\hline $\begin{array}{l}\text { Keokuk County, Iowa, USA } \\
\text { Rural households (117) } \\
\text { (Pavilonis et al., 2013) }\end{array}$ & $\begin{array}{l}\text { The area where the family spend most of their } \\
\text { time }\end{array}$ & 117 & AM: 0.32; GM: 0.21 (GSD: 2.51) \\
\hline $\begin{array}{l}\text { Missoula, MT, USA } \\
\text { Wood stove homes (50) } \\
\text { (McNamara et al., 2013) }\end{array}$ & Samples from common living area & 100 & AM: 9.2 (SD:12.4) \\
\hline Nepal and Malawi & Short cooking-time samples taken from & 16 & AM: 100 (SD: 113) \\
\hline $\begin{array}{l}\text { Wood-,dung-, and maize crop residue-burning- } \\
\text { homes (37) }\end{array}$ & $\begin{array}{l}\text { Nepalese wood-burning homes } \\
\text { Short cooking-time samples taken from }\end{array}$ & $\begin{array}{l}15 \\
4\end{array}$ & $\begin{array}{l}\text { AM: } 498 \text { (SD: 291) } \\
\text { AM: } 201 \text { (SD: 217) }\end{array}$ \\
\hline (Semple et al., 2010) & $\begin{array}{l}\text { Nepalese dung-burning homes } \\
\text { Short cooking-time samples taken from } \\
\text { Malawian wood-burning homes } \\
\text { Short cooking-time samples taken from } \\
\text { Malawian maize crop residue-burning homes }\end{array}$ & 2 & AM: 1609 (SD: 2211) \\
\hline Netherlands & Living room samples from farm homes & 72 & GM: 1.04 (GSD: 2.84) \\
\hline $\begin{array}{l}\text { Farm homes (9) and non-farm homes (7) } \\
\text { (Noss et al., 2008) }\end{array}$ & Living room samples from non-farm homes & 56 & GM: 0.36 (GSD: 2.33) \\
\hline $\begin{array}{l}\text { New Orleans, USA } \\
\text { Flooded single-family houses (3) } \\
\text { (Chew et al., 2006) }\end{array}$ & (1) & 9 & Range GM: 17-139 \\
\hline $\begin{array}{l}\text { New Orleans, USA } \\
\text { Residents (20) } \\
\text { (Rao et al., 2007) }\end{array}$ & $\begin{array}{l}\text { Homes (samples collected from the moldiest } \\
\text { room of the house) }\end{array}$ & 20 & GM: 23.3 (GSD: 5.6) \\
\hline $\begin{array}{l}\text { New Orleans, Louisiana, USA } \\
\text { Homes stratified by water damage (31) } \\
\text { (Riggs et al., 2008) }\end{array}$ & Homes & 31 & GM: 40.2 \\
\hline \multirow[t]{2}{*}{$\begin{array}{l}\text { Northeast Scotland and in west coast of Ireland } \\
\text { Households (100) } \\
\text { (Semple et al., 2012) }\end{array}$} & $\begin{array}{l}\text { The main living area of the coal-burning, peat- } \\
\text { burning, wood-burning, gas-cooking, and } \\
\text { "smoking" homes }\end{array}$ & 100 & AM: 5.69 \\
\hline & Living room or family room & 40 & Range GM: $0.5-2.2$ (Range GSD: $1.6-4.0$ ) \\
\hline
\end{tabular}


Table 2 (continued)

\begin{tabular}{|c|c|c|c|}
\hline $\begin{array}{l}\text { Study location } \\
\text { Type of buildings (number of buildings) }\end{array}$ & $\begin{array}{l}\text { Sampling location/housing and other } \\
\text { characteristics }\end{array}$ & $\mathrm{n}^{*}$ & Endotoxin $\left(\mathrm{EU} / \mathrm{m}^{3}\right)$ \\
\hline \multicolumn{4}{|l|}{$\begin{array}{l}\text { Northern California (Bay area), USA } \\
\text { Single-family homes (10) } \\
\text { (Chen and Hildemann, 2009) }\end{array}$} \\
\hline Odisha, India & Homes using biomass fuels for cooking ( 35 & 35 & Median: 350 \\
\hline $\begin{array}{l}\text { Homes (70) } \\
\text { (Padhi et al., 2016) }\end{array}$ & $\begin{array}{l}\text { homes) } \\
\text { Homes using LPG gas for cooking ( } 35 \text { homes) }\end{array}$ & 35 & Median: 110 \\
\hline Paris, France & Homes during the 1 st visit & 140 & GM: 0.592 (GSD: 4.175 \\
\hline $\begin{array}{l}\text { Homes (140) } \\
\text { (Dassonville et al., 2008) }\end{array}$ & Homes during the 2 nd visit & 140 & GM: 0.553 (GSD: 2.921 \\
\hline $\begin{array}{l}\text { Prince Edward Island, Canada } \\
\text { Homes (332) } \\
\text { (Dales et al., 2006) }\end{array}$ & Child's bedroom & 332 & GM: 0.49 (GSD: 3.49) \\
\hline Regina, Saskatchewan (SK), Canada & Homes during winter & 146 & Range: $0.02-1.5$ \\
\hline $\begin{array}{l}\text { Homes (146) } \\
\text { (Wheeler et al., 2011) }\end{array}$ & Homes during summer & 146 & Range: $0.06-4.1$ \\
\hline Riverside and Whittier, California & Riverside homes & 31 & AM: 0.58 (SD: 0.42) \\
\hline $\begin{array}{l}\text { Houses from } 2 \text { geographical locations (12) } \\
\text { (Delfino et al., 2011) }\end{array}$ & Whittier homes & 78 & AM: 1.49; (SD: 1.29 \\
\hline $\begin{array}{l}\text { Santiago, Chile } \\
\text { Houses (44) } \\
\text { (Barraza et al., 2016) }\end{array}$ & Living room & 44 & AM: 0.099; GM: 0.077 (GSD: 2.1) \\
\hline $\begin{array}{l}\text { Singapore } \\
\text { Residential apartment (1) } \\
\text { (Balasubramanian et al., 2012) } \\
\text { School studies }\end{array}$ & Different rooms & 42 & Range AM:6-39 (Range SD: 2-60) \\
\hline $\begin{array}{l}\text { Brisbane, Australia } \\
\text { Urban schools (25) } \\
\text { (Salonen et al., 2013) }\end{array}$ & Teaching classrooms & 74 & GM: 1.2; AM: 2.7 (SD: 3.2) \\
\hline $\begin{array}{l}\text { Denmark } \\
\text { "Wet (8) and dry" (7) schools } \\
\text { (Ebbehøj et al., 2005; Holst et al., 2015a) }\end{array}$ & $\begin{array}{l}\text { Schools with and without obvious water } \\
\text { damage and clearly visible patches of mold } \\
\text { growth }\end{array}$ & 15 & GM: 9.34 (GSD: 2.92) \\
\hline $\begin{array}{l}\text { Denver, CO, USA } \\
\text { Urban schools (18) } \\
\text { (Menetrez et al., 2009) }\end{array}$ & Teaching classrooms & 18 & AM: 9.2 (SD: 6.9) \\
\hline $\begin{array}{l}\text { Denver, CO, USA } \\
\text { School (1) } \\
\text { (Rabinovitch et al., 2005) } \\
\text { Office studies }\end{array}$ & Schools & 16 & GM: 0.07 (GSD: 3.74) \\
\hline $\begin{array}{l}\text { Singapore } \\
\text { Air conditioned office (1) } \\
\text { (Balasubramanian et al., 2012) }\end{array}$ & Room sample & 2 & AM: 6 (SD: 4) \\
\hline
\end{tabular}

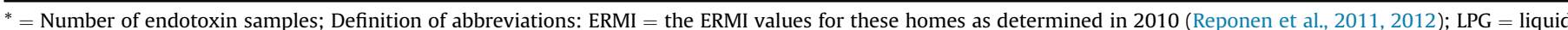

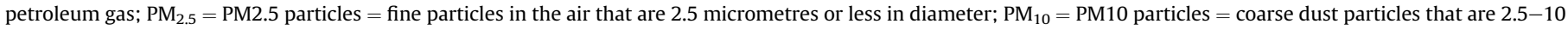
micrometers in diameter.

samples). In all the studies endotoxins were assayed with a LALbased bioassay (e.g. kinetic turbidimetric LAL, endpoint chromogenic LAL or kinetic chromogenic LAL) (Chun et al., 2002; Thorne et al., 2009). Other detailed information about the selected studies is presented in Table S3 in the SM.

In residential settings, the reported average concentrations of endotoxin in indoor air varied between 0.04 and $1610 \mathrm{EU} / \mathrm{m}^{3}$ (Park et al., 2000, 2001b; von Mutius et al., 2000; Bouillard et al., 2006; Chew et al., 2006; Dales et al., 2006; Horick et al., 2006; Rao et al., 2007; Dassonville et al., 2008; Noss et al., 2008; Riggs et al., 2008; Chen and Hildemann, 2009; Reponen et al., 2010; Semple et al., 2010; Tager et al., 2010; Delfino et al., 2011; Mazique et al., 2011; Wheeler et al., 2011; Balasubramanian et al., 2012; Frankel et al., 2012a; Semple et al., 2012; Hansel et al., 2013; McNamara et al., 2013; Pavilonis et al., 2013; Adhikari et al., 2014; Bari et al., 2014; Escobedo et al., 2014; Bose et al., 2015; Barraza et al., 2016; Padhi et al., 2016). The lowest mean endotoxin concentration was reported in Maryland, USA, during summer season (Mazique et al., 2011) and the highest in Malawian maize crop residue-burning homes during cooking time (Semple et al., 2010).

Several studies reported that endotoxin concentrations in indoor air are generally higher in the summer season than in the winter season (Tager et al., 2010; Wheeler et al., 2011; Pavilonis et al., 2013; Bari et al., 2014) and that geographical locations affect the concentrations (Delfino et al., 2011). Although in urban residential studies, concentrations of endotoxin were generally $<1$ $\mathrm{EU} / \mathrm{m}^{3}$ in residencies with open combustion processes (such as burning coal, peat, or wood fuel, or using a gas cooker or stove) or where there was at least one smoker, the mean airborne endotoxin concentrations can be much higher generally $<10 \mathrm{EU} / \mathrm{m}^{3}$ but in some cases over $20 \mathrm{EU} / \mathrm{m}^{3}$ and even up to $1610 \mathrm{EU} / \mathrm{m}^{3}$ (when cooking by burning maize crop residue) (Semple et al., 2010, 2012). In addition, an ultrasonic humidifier was reported to highly affect endotoxin concentrations. In a theoretical study by Anderson et al. (2007), the calculated endotoxin concentrations in homes with an ultrasonic humidifier were the following; $93 \mathrm{EU} / \mathrm{m}^{3}$ (when $25 \mathrm{EU} /$ $\mathrm{ml}$ endotoxin in water), $3729 \mathrm{EU} / \mathrm{m}^{3}$ (with $1000 \mathrm{EU} / \mathrm{ml}$ endotoxin in water) and $141,687 \mathrm{EU} / \mathrm{m}^{3}$ (with $38,000 \mathrm{EU} / \mathrm{ml}$ endotoxin in water).

In urban areas, the mean concentration of airborne endotoxins was generally lower than in rural areas (Park et al., 2000, 2001b), and it was higher in farming houses than in non-farming houses (Noss et al., 2008). Moreover, samples collected in high-density farming areas had higher mid-range endotoxin levels (MuellerAnneling et al., 2004). Moniruzzaman et al. (2012) reported that direct contact with farming animals or indirect contact from carrying dust (loaded with endotoxin) on clothes and shoes from the 
stables are direct sources of endotoxin.

In a school environment, the reported average endotoxin concentrations in indoor air varied between 0.07 and $9.30 \mathrm{EU} / \mathrm{m}^{3}$ (Ebbehøj et al., 2005; Rabinovitch et al., 2005; Menetrez et al., 2009; Salonen et al., 2013; Holst et al., 2015a), the average being the highest in Denmark (Ebbehøj et al., 2005; Holst et al., 2015a) and the lowest in Denver, USA (Rabinovitch et al., 2005). Generally, in school environments, the mean concentrations of endotoxins in indoor air were higher than those reported in several urban residential settings, such as in residences in Northern California (Chen and Hildemann, 2009), Boston (Park et al., 2000), Canada (Dales et al., 2006), and Belgium (Bouillard et al., 2006). In urban areas, schools are therefore at least as important as home environments as a source of endotoxins. In an office environment in Singapore the mean endotoxin concentration was $6 \mathrm{EU} / \mathrm{m}^{3}$.

All reported (see Table 2) mean airborne endotoxin levels in undamaged (either by flooding, mold, or water) buildings without wood-, dung- or maize crop residue-burning indoor environments (generally $\mathrm{GM}<10 \mathrm{EU} / \mathrm{m}^{3}$ in non-flooded areas) were much lower than the recommended exposure limit (REL) for endotoxins suggested by HCN (Health Council of the Netherlands) (HCN, 2010). HCN (2010) proposes an 8-hour time-weighted average (TWA) of $90 \mathrm{EU} / \mathrm{m}^{3}$, which represents a no-observed-effect level (NOEL) for a worker inhaling that level of endotoxins over a 40-year work life. However, several studies were found indicating that even at low levels of endotoxins, exposure may be associated with an increased prevalence of wheezing (Park et al., 2001a), sensitization (Bolte et al., 2003), and asthma (Thorne et al., 2005).

It should be noted that caution is needed when comparing airborne endotoxin concentrations from different studies as field studies show important differences in sampling strategies (e.g., different sampling periods), although the method of analysis remains the same (Rylander, 2002; Duquenne et al., 2013). Studies employing different sampling strategies are not directly comparable.

\subsection{Effect of different environmental factors on the levels of endotoxin in indoor environments}

Table 3 summarizes the relationship between environmental factors and the endotoxin loads in settled floor dust and the concentration of endotoxins in indoor air. It should be noted that findings from all studies with concentrations of endotoxins in settled floor dust were included in Table 3 regardless of the expression units used $\left(\mathrm{EU} / \mathrm{mg}\right.$ or $\left.\mathrm{EU} / \mathrm{m}^{2}\right)$. Both units were reported to be highly correlated with each other (Thorne et al., 2005).

Table 3 shows that there is extremely strong scientific evidence that the age of building, cleaning/cleanliness, farm or rural living, flooring materials (the presence of carpets), number of occupants (in a residence or in a school), the presence of dogs or cats indoors, and relative humidity affect the endotoxin loads in settled floor dust. In addition, there is strong scientific evidence that, children living in the home/the presence of children, moisture/dampness damages, the presence of animals (dog, cat, vermin, or cockroaches) or pet owner indoors, season, temperature and tobacco smoking also influence endotoxin concentrations in settled dust. Correspondingly, there is extremely strong scientific evidence that the presence of pets (especially dog), and strong scientific evidence

Table 3

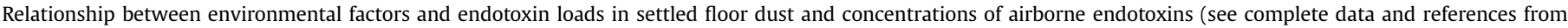
Table S5).

\begin{tabular}{|c|c|c|c|c|}
\hline Environmental factors & $\begin{array}{l}\text { Association with loads or } \\
\text { concentrations of endotoxins } \\
\text { in floor dust }\end{array}$ & $\begin{array}{l}\text { No relationship with loads/ } \\
\text { concentrations of endotoxins in } \\
\text { floor dust }\end{array}$ & $\begin{array}{l}\text { Association with } \\
\text { concentrations of } \\
\text { endotoxins in indoor air }\end{array}$ & $\begin{array}{l}\text { No relationship with } \\
\text { concentrations of } \\
\text { endotoxins in indoor air }\end{array}$ \\
\hline Age of building/housing unit year category & $* * *$ & * & NR & NR \\
\hline $\begin{array}{l}\text { Cat ownership/dog ownership/pet ownership/ } \\
\text { presence of pet owner }\end{array}$ & ** & $* *$ & NR & * \\
\hline $\begin{array}{l}\text { Children living in the home/presence of } \\
\text { children }\end{array}$ & $* *$ & NR & NR & NR \\
\hline $\begin{array}{l}\text { Cleaning (floor vacuuming/use of a vacuum, } \\
\text { wet mop cleaning)/cleanliness/cleaning } \\
\text { frequency/dusting }\end{array}$ & $* * *$ & * & ** & $*$ \\
\hline $\begin{array}{l}\text { Farm or rural living/agricultural activities/ } \\
\text { animal husbandry }\end{array}$ & $* * *$ & NR & * & $*$ \\
\hline Floor materials/flooring materials & $* * *$ & $* *$ & $*$ & $*$ \\
\hline $\begin{array}{l}\text { Moisture/dampness damages/visible } \\
\text { dampness or mould/water damage/metrics } \\
\text { of moisture damage }\end{array}$ & ** & $* * *$ & $* *$ & * \\
\hline $\begin{array}{l}\text { Mouse infestation/problems or sign of with } \\
\text { mice in the previous } 12 \text { months/mice in the } \\
\text { house }\end{array}$ & $*$ & NR & ** & NR \\
\hline $\begin{array}{l}\text { Number of occupants/a high household } \\
\text { crowding index/family size }\end{array}$ & $* * *$ & * & $* *$ & $*$ \\
\hline Presence of cat & $* * *$ & $*$ & * & NR \\
\hline Presence of cockroaches & $* *$ & NR & $*$ & NR \\
\hline Presence of dog & $* * *$ & NR & $* *$ & $*$ \\
\hline Presence of furry pets/number of furry pets & NR & $* *$ & $*$ & $*$ \\
\hline $\begin{array}{l}\text { Presence of pets/animals indoors (dog, cat or } \\
\text { vermin) }\end{array}$ & ** & $* *$ & $* * *$ & $*$ \\
\hline Relative humidity of indoor and/or outdoor air & $* * *$ & $* *$ & $* *$ & $* *$ \\
\hline Seasonality/season/seasonal effects & $* *$ & $* *$ & $* *$ & $*$ \\
\hline Temperature in indoor/outdoor & $* *$ & $* *$ & $* *$ & $*$ \\
\hline Tobacco smoking inside & $* *$ & $*$ & $* *$ & $* *$ \\
\hline
\end{tabular}

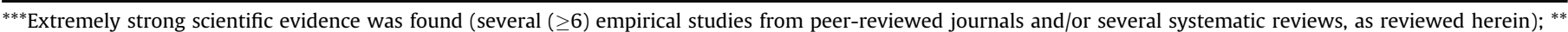

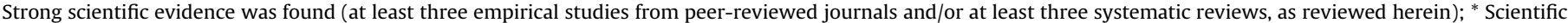
evidence was found (one or two empirical studies from peer-reviewed journals); NR = Not reported.

Note! Table 3 includes only factors with extremely strong/strong scientific evidence. Factors with "only" scientific evidence were only presented in S4 and S5 in SM. 
that cleaning/cleanliness, moisture/dampness damages, number of occupants, problems with/or sign of mice in the previous 12 months, relative humidity, season/seasonality, temperature and tobacco smoking affect the concentrations of endotoxins in indoor air. Despite strong scientific findings, it should be noted that with several factors (e.g. temperature and relative humidity) contradictory findings were found for both indoor air and settled dust.

\subsubsection{Age of the houses}

Despite strong scientific evidence that the age of houses is related to the loads of endotoxins in settled floor dust (Douwes et al., 1998; Bischof et al., 2002; Dales et al., 2006; Thorne et al., 2009; AlAli et al., 2010), no association between the age of school buildings and concentrations of endotoxins in settled floor dust has been found (Sheehan et al., 2012).

\subsubsection{Cleaning/cleanliness}

Recently, cleaning/cleanliness has been reported as an important predicting factor of endotoxin levels inside the home, both in settled dust (Thorne et al., 2009; Pavilonis et al., 2013) and in indoor air (Sebastian et al., 2006). Higher levels of domestic endotoxins in settled floor dust have been associated with less vacuuming (Bischof et al., 2002; Wickens et al., 2003b; Leung et al., 2010) while frequent dusting has been shown to be related to lower airborne endotoxin concentrations (Mazique et al., 2011), and wet mop cleaning with lower settled dust endotoxin levels (Perzanowski et al., 2006). Ownby et al. (2013) reported that home occupancy (occupants per room) and cleanliness were consistently correlated to endotoxins in all home sites. Data from Ownby et al. (2013) suggest that reducing occupancy and improving home cleanliness would reduce home endotoxin concentrations more than removing pets (cats or dogs) from the home. Finally, Pavilonis et al. (2013) demonstrated that, excluding home cleanliness, the majority of agricultural and housing characteristics were found to be poorly associated with concentrations of particulates and endotoxins.

\subsubsection{Farmhouses versus other rural and urban houses}

Several studies have found that endotoxin levels were significantly higher in floor dust from farmhouses compared to other rural and urban homes (Gereda et al., 2000; von Mutius et al., 2000; Waser et al., 2004; Vedanthan et al., 2006; Morcos et al., 2011; Barnig et al., 2013). However, no difference was found between endotoxin concentrations in the air of urban and rural houses (Park et al., 2000; Barnig et al., 2013), and there was no reported correlation between airborne and settled dust endotoxin levels (Barnig et al., 2013).

\subsubsection{The type of floor materials}

Having a carpet as a flooring material has been strongly associated with higher loads of endotoxin in the settled floor dust in several studies (Wickens et al., 2003b; Perzanowski et al., 2006; Giovannangelo et al., 2007; Mazique et al., 2011; Holst et al., 2015b; Thorne et al., 2015). It has also been reported that the presence of wall-to-wall carpeting may lead to higher dust loading and higher settled dust endotoxin concentrations (Mazique et al., 2011). On the other hand, linoleum flooring was associated with lower airborne endotoxin concentrations (Mazique et al., 2011) and smooth floor was associated with lower endotoxin loads in floor dust (Thorne et al., 2015).

\subsubsection{The number of occupants and the presence of children}

The number of household occupants correlate with endotoxin levels in settled dust and in indoor air (Dassonville et al., 2008; Thorne et al., 2009; Chen et al., 2012; Rennie et al., 2012; McNamara et al., 2013), and consequently, a large family size is one notable predictor of high domestic endotoxin levels (Wickens et al., 2003b; Waser et al., 2004; Thorne et al., 2005). Several studies have also found that the presence of children is potential contributor to increased endotoxin levels in house dust (Waser et al., 2004; Thorne et al., 2009, 2015). Recently, Jacobs et al. (2014) reported that factors affecting endotoxin levels in European schools differ by country. In general, endotoxin levels were higher in lower grades and in classrooms with higher occupancy (Jacobs et al., 2014).

\subsubsection{Pets}

In several studies, dogs and/or cats have been identified as a major source of endotoxins in indoor environments both in settled floor dust and in indoor air (Bischof et al., 2002; Rylander, 2002; Bottcher et al., 2003; Rabinovitch et al., 2006; Mazique et al., 2011; Thorne et al., 2015). It has been reported that children living in a household with dogs or a cat were exposed to high levels of endotoxins (Rabinovitch et al., 2006). Although increased household endotoxin concentrations were strongly associated with pet ownership (Thorne et al., 2009), dog and cat ownership was significantly associated with increased personal but not stationary sampling (Delfino et al., 2011). Delfino et al. (2011) concluded that personal dust cloud exposures may be the predominant driver of personal endotoxin exposure and that regional differences (weather and local sources) influencing ambient endotoxins are important to consider when assessing personal endotoxin exposure. Sheehan et al. (2012) reported that levels of dog and cat allergens were associated with higher concentrations of endotoxins in schools. Given that there were no pets in the schools, this association may indicate that children are tracking endotoxins into the schools along with pet allergens, and the number of "dog owner" families may affect the levels of endotoxins in studied classrooms.

\subsubsection{Climate factors}

Though it has been reported that geographical locations affect the concentrations of endotoxins (Delfino et al., 2011; Kallawicha et al., 2015) and that airborne endotoxin concentrations tended to be higher during the autumn and spring seasons (Mazique et al., 2011; Moon et al., 2014), and higher in the summer than the winter season (Tager et al., 2010; Wheeler et al., 2011; Pavilonis et al., 2013; Bari et al., 2014), the results of the reviewed studies data on the possible effects of climate factors, such as humidity and temperature on endotoxin levels in both indoor air and settled dust were contradictory. Several studies found that higher relative humidity leads to higher airborne endotoxin levels (Park et al., 2000; Wickens et al., 2003b), and it has been suggested that relative humidity may be an important factor for controlling endotoxin exposure indoors (Park et al., 2000). On the other hand, an increase in relative humidity has been found to lead to a decrease in airborne endotoxin concentrations (Salonen et al., 2013). It has also been reported that humidity was not associated with airborne endotoxin concentrations (Mazique et al., 2011; Hwang et al., 2016). It has been assumed that humid climates are associated with higher endotoxin levels. Indeed, the growth of endotoxin-producing bacteria, Gram-negative bacteria, is better supported in environments with high water activity, such as wet surfaces and stagnant water (Salonen et al., 2013). Several studies have found that relative humidity affects dust endotoxin levels (Park et al., 2000; Wickens et al., 2003a, 2003b; Thorne et al., 2005; Dales et al., 2006). However, there are also many contrary findings suggesting no association between relative humidity and endotoxin levels in settled floor dust (Douwes et al., 1998; Bischof et al., 2002; Chen et al., 2012), or showing only a weak effect (Salonen et al., 2013).

Concerning the effects of temperature on indoor levels of 
endotoxins, findings are contradictory as well, both for endotoxin concentrations in indoor air and endotoxin loads in settled floor dust. Although numerous studies have reported that temperature affects endotoxin loads in settled floor dust (Park et al., 2000; Singh et al., 2011; Salonen et al., 2013) and endotoxin concentrations in indoor air (Thorn et al., 2002; Salonen et al., 2013; Hwang et al., 2016), there are other studies in which no such association was found (Douwes et al., 1998; Bischof et al., 2002; Mazique et al., 2011; Chen et al., 2012). In some studies temperature increases were associated with lower endotoxin concentrations in indoor air (Park et al., 2000; Salonen et al., 2013) and higher loads in settled floor dust (Salonen et al., 2013).

\subsubsection{Tobacco smoking}

Tobacco smoking has been reported to influence both the concentrations of endotoxins in indoor air (Larsson et al., 2004; Sebastian et al., 2006; Rennie et al., 2012) and the endotoxin loads in settled dust significantly (Hasday et al., 1999; Rennie et al., 2008; Thorne et al., 2009; Leung et al., 2010). Hasday et al. (1999) reported that high bacterial endotoxin levels are present in cigarette smoke because smoke from one cigarette contains approximately 1200 EU of bioactive LPS (endotoxin). Findings regarding the effect of tobacco smoke on endotoxin concentrations in indoor air are contradictory. For example Park et al. (2001b) and Pavilonis et al. (2013) did not find a relationship between tobacco smoking and endotoxin concentrations in indoor air.

\subsubsection{Dampness}

There is strong scientific evidence that moisture/dampness damages/visible mold/damp affect endotoxin loads in settled dust (Bischof et al., 2002; El Sharif et al., 2004; Jacobs et al., 2012; Casas et al., 2013), and endotoxin concentrations in indoor air (Park et al., 2000, 2001b; Tavernier et al., 2006; Adhikari et al., 2014). Adhikari et al. (2014) reported that endotoxin levels in air were significantly greater in high Environmental Relative Moldiness Index (ERMI) homes, suggesting that both short-term and long-term mold contamination in homes could be linked with bacterial concentrations in house dust. However, only the current mold status was associated with airborne bacterial concentrations. Reponen et al. (2010) found that homes that had a moldy odor also had the highest concentrations of measured endotoxins, and moldy odor may be more strongly associated with the concentrations of airborne endotoxins than with the concentrations measured in dust samples. However, most studies failed to detect an association between endotoxin levels and localized moisture damages (Douwes et al., 1998; Gereda et al., 2001; Wickens et al., 2003b; Chen et al., 2007; Giovannangelo et al., 2007; Johansson et al., 2011).

\subsubsection{Outdoor air}

Although several environmental factors affecting indoor endotoxin levels have been observed (Heinrich et al., 2001; Park et al., 2001b; Waser et al., 2004), the contribution from the outdoor environment has not been well characterized (Menetrez et al., 2001). Indeed, it has been reported that in temperate climates or during the warmer months of the year in colder climates, it is possible that outdoor endotoxin levels have an influence on indoor levels, especially when the windows are open or if the building is not tightly sealed (Park et al., 2000).

The relationship between environmental factors and the endotoxin loads in settled floor dust and the concentrations of endotoxins in indoor air is summarized in Table S4 in the SM. The references are available in Table S5 in the SM.

\section{Conclusions}

Knowledge of generally existing levels of endotoxins in indoor air and in settled floor dust as well as the factors influencing endotoxin levels in indoor environments is needed to correctly understand field data and to recognize "abnormal" levels of endotoxins. This review may be used as a guide to aid in the interpretation of endotoxin levels in different indoor environments. The analysis of the data showed that the reported indoor loads of endotoxins in settled floor dust, as well as the concentrations of endotoxin in indoor air varied widely within an indoor environment and between different indoor environments, being $660-107,000 \mathrm{EU} / \mathrm{m}^{2}$ and $0.04-1610 \mathrm{EU} / \mathrm{m}^{3}$ in residential homes; 2180-48,000 EU/m $\mathrm{m}^{2}$ and $0.07-9.30 \mathrm{EU} / \mathrm{m}^{3}$ in schools; and $2700-12,890 \mathrm{EU} / \mathrm{m}^{2}$ and $6 \mathrm{EU} / \mathrm{m}^{3}$ in offices. Our review suggests that the age of houses, cleaning, farm or rural living, flooring materials (the presence of carpets), number of occupants, the presence of dogs or cats indoors, and relative humidity were the strongest determinants for endotoxin loads in settled floor dust, while the presence of pets (especially dogs) were the strongest contributing factors for airborne endotoxin concentrations. Concerning the effect of several environmental factors on endotoxin levels, the literature findings are inconsistent and additional studies are needed. This review recommends that further efforts should be made to create a standardized, uniform sampling methodology for endotoxins and to investigate the impact of different local factors in different climate regions.

\section{Appendix A. Supplementary data}

Supplementary data related to this article can be found at http:// dx.doi.org/10.1016/j.atmosenv.2016.08.018.

\section{References}

Adhikari, A., Kettlesona, E.M., Vesper, S., Kumar, S., Popham, D.L., Schaffer, C. Indugula, R., Chatterjee, K., Allama, K.K., Grinshpun, S.A., Reponen, T., 2014 Dustborne and airborne Gram-positive and Gram-negative bacteria in high versus low ERMI homes. Sci. Total Environ. 482-483, 92-99.

Akpinar-Elci, M., White, S.K., Siegel, P.D., Park, J.-H., Visotcky, A., Kreiss, K., CoxGanser, J.M., 2013. Markers of upper airway inflammation associated with microbial exposure and symptoms in occupants of a water-damaged building. Am. J. Ind. Med. 56, 522-530.

AlAli, W., Custovic, A., Simpson, A., Khowy, A., Woodcock, A., 2010. Household characteristics and allergen and endotoxin levels in Aleppo, Syrian Arab Republic. East. Mediterr. Health J. 16, 717-724.

Anderson, W.B., Dixon, D.G., Mayfield, C.I., 2007. Estimation of endotoxin inhalation from shower and humidifier exposure reveals potential risk to human health. J. Water Health.

Balasubramanian, R., Nainar, P., Rajasekar, A., 2012. Airborne bacteria, fungi, and endotoxin levels in residential microenvironments: a case study. Aerobiologia 28, 375-390.

Bari, M.A., MacNeill, M., Kindzierski, W.B., Wallace, L., Hérox, M.E., Wheeler, A.J., 2014. Predictors of coarse particulate matter and associated endotoxin concentrations in residential environments. Atmos. Environ. 92, 221-230.

Barnig, C., Reboux, G., Roussel, S., Casset, A., Sohy, C., Dalphin, J.-C., Blay, F. d., 2013. Indoor dust and concentrations of endotoxin in urban and rural environments. Lett. Appl. Microbiol. 56, 161-167.

Barraza, F., Jorquera, H., Heyer, J., Palma, W., Edwards, A.M., Muñoz, M., Valdivia, G., Montoya, L.D., 2016. Short-term dynamics of indoor and outdoor endotoxin exposure: case of Santiago, Chile, 2012. Environ. Int. 92-93, 97-105.

Bischof, W., Koch, A., Gehring, U., Fahlbusch, B., Wichmann, H.E., Heinrich, J., 2002. Predictors of high endotoxin concentrations in the settled dust of German homes. Indoor Air 12, 2-9.

Bolte, G., Bischof, W., Borte, M., Lehmann, I., Wichmann, H.E., Heinrich, J., Group, L.S., 2003. Early endotoxin exposure and atopy development in infants: results of a birth cohort study. Clin. Exp. Allergy 33, 770-776.

Bose, S., Rivera-Mariani, F., Chen, R., Williams, D., Belli, A., Aloe, C. McCormack, M.C., Breysse, P.N., Hansel, N.N., 2015. Domestic exposure to endotoxin and respiratory morbidity in former smokers with COPD. Indoor Air. http://dx.doi.org/10.1111/ina.12264.

Bottcher, M.F., Bjorksten, B., Gustafson, S., Voor, T., Jenmalm, M.C., 2003. Endotoxin levels in Estonian and Swedish house dust and atopy in infancy. Clin. Exp. Allergy 33, 295-300. 
Bouillard, L.A., Devleeschouwer, M.J., Michel, O., 2006. Characteristics of the home bacterial contamination and endotoxin related release. J. de Pharm. de Belg. 61, 63-66.

Casas, L., Tischer, C., Wouters, I.M., Valkonen, M., Gehring, U., Doekes, G., Torrent, M., Pekkanen, J., Garcia-Esteban, R., Hyvärinen, A., Heinrich, J., Sunyer, J., 2013. Endotoxin, extracellular polysaccharides, and $\beta(1-3)$-glucan concentrations in dust and their determinants in four European birth cohorts: results from the HITEA project. Indoor Air 23, 208-218.

Chen, Q. Hildemann, L.M., 2009. The effects of human activities on exposure to particulate matter and bioaerosols in residential homes. Environ. Sci. Technol. 43, 4641-4646.

Chen, C.M., Mielck, A., Fahlbusch, B., Bischof, W., Herbarth, O., Borte, M., Wichmann, H.E., Heinrich, J., 2007. Social factors, allergen, endotoxin, and dust mass in mattress. Indoor Air 17, 384-393.

Chen, C.-M., Thiering, E., Doekes, G., Zock, J.-P., Bakolis, I., Norbck, D., Sunyer, J., Villani, S., Verlato, G., Tubel, M., Jarvis, D., Heinrich, J., 2012. Geographical variation and the determinants of domestic endotoxin levels in mattress dust in Europe. Indoor Air 24-32.

Chew, G.L., Wilson, J., Rabito, F.A., Grimsley, F., Iqbal, S., Reponen, T., Muilenberg, M.L., Thorne, P.S., Dearborn, D.G., Morley, R.L., 2006. Mold and endotoxin levels in the aftermath of hurricane katrina: a pilot project of homes in new orleans undergoing renovation. Environ. Health Perspect. 114, 1883-1889.

Chun, D.T., Chew, V., Bartlett, K., Gordon, T., Jacobs, R.R., Larsson, B.M., Lewis, D.M., Liesivuori, J., Michel, O., Rylander, R., Thorne, P.S., White, E.M., Gunn, V.C., Wurtz, H., 2002. Second inter-laboratory study comparing endotoxin assay results from cotton dust. Ann. Agric. Environ. Med. 9, 49-53.

Dales, R., Miller, D., Ruest, K., Guay, M., Judek, S., 2006. Airborne endotoxin is associated with respiratory illness in the first 2 years of life. Environ. Health Perspect. 114, 610-614.

Dassonville, C., Demattei, C., Vacquier, B., Bex-Capelle, V., Seta, N., Momas, I., 2008. Indoor airborne endotoxin assessment in homes of Paris newborn babies. Indoor Air 18, 480-487.

Delfino, R.J., Staimer, N., Tjoa, T., 2011. Personal endotoxin exposure in a panel study of school children with asthma. Environ. Health 10, 1-14.

Douwes, J., Doekes, G., Heinrich, J., Koch, A., Bischof, W., Brunekreef, B., 1998. Endotoxin and $\mathrm{B}(1 \rightarrow 3)$-glucan in house dust and the relation with home characteristics: a pilot study in 25 German houses. Indoor Air 8, 255-263.

Duchaine, C., Thorne, P.S., Mériaux, A., Grimard, Y., Whitten, P., Cormier, Y., 2001. Comparison of endotoxin exposure assessment by bioaerosol impinger and filter-sampling methods. Appl. Environ. Microbiol. 67, 2775-2780.

Duquenne, P., Marchand, G., Duchaine, C., 2013. Review. Measurement of endotoxins in bioaerosols at workplace: a critical review of literature and a standardization issue. Ann. Occup. Hyg. 57, 137-172. Available online at. http:// annhyg.oxfordjournals.org/content/early/2012/09/20/annhyg.mes051.full. pdf + html.

Ebbehøj, N.E., Meyer, H.W., W€urtz, H., Suadicani, P., Valbjørn, O., Sigsgaard, T., Gyntelberg, F., 2005. Molds in floor dust, building-related symptoms, and lung function among male and female schoolteachers. Indoor Air 15, 7-16.

El Sharif, N., Douwes, J., Hoet, P.H., Doekes, G., Nemery, B., 2004. Concentrations of domestic mite and pet allergens and endotoxin in Palestine. Allergy 59, 623-631.

Escobedo, L.E., Champion, W.M., Li, N., Montoya, L.D., 2014. Indoor air quality in Latino homes in Boulder, Colorado. Atmos. Environ. 92, 69-75.

Foarde, K., Berry, M., 2004. Comparison of biocontaminant levels associated with hard vs carpet floors in non-problem schools: results of a year long study. J. Expo. Anal. Environ. Epidemiol. 14, 41-48.

Frankel, M., Bekö, G., Timm, M., Gustavsen, S., Hansen, E.W., Madsen, A.M., 2012a. Seasonal variation of indoor microbial exposures and their relations to temperature, relative humidity and air exchange rates. Am. Soc. Microbiol. http:// dx.doi.org/10.1128/AEM.02069-12.

Frankel, M., Timm, M., Hansen, E.W., Madsen, A.M., 2012b. Comparison of sampling methods for the assessment of indoor microbial exposure. Indoor Air 22, 405-414.

Gehring, U., Bolte, G., Borte, M., Bischof, W., Fahlbusch, B., Wichmann, H.E., Heinrich, J., 2001. Exposure to endotoxin decreases the risk of atopic eczema in infancy: a cohort study. J. Allergy Clin. Immunol. 108, 847-854.

Gehring, U., Bischof, W., Fahlbusch, B., Wichmann, H.-E., Heinrich, J., 2002. House dust endotoxin and allergic sensitization in children. Am. J. Respir. Crit. Care Med. 166, 939-944.

Gehring, U., Strikwold, M., Schram-Bijkerk, D., Weinmayr, G., Genuneit, J., Nagel, G., Wickens, K., Siebers, R., Crane, J., Doekes, G., Di Domenicantonio, R., Nilsson, L., Priftanji, A., Sandin, A., El-Sharif, N., Strachan, D., van Hage, M., v. M. E., Brunekreef, B., 2008. Asthma and allergic symptoms in relation to house dust endotoxin: phase two of the international study on asthma and allergies in childhood (ISAAC II). Clin. Exp. Allergy 38, 1911-1920.

Gereda, J.E., Leung, D.Y., Liu, A.H., 2000. Levels of environmental endotoxin and prevalence of atopic disease. J. Am. Med. Assoc. 284, 1652-1653.

Gereda, J.E., Klinner, M.D., Price, M.R., Leung, D.Y., Liu, A.H., 2001. Metropolitan home living conditions associated with indoor endotoxin levels. J. Allergy Clin. Immunol. 107, 790-796.

Giovannangelo, M., Gehring, U., Nordling, E., Oldenwening, M., Terpstra, G., Bellander, T., Hoek, G., Heinrich, J., Brunekreef, B., 2007. Determinants of house dust endotoxin in three European countries - the AIRALLERG study. Indoor Air 17, $70-79$.
Hansel, N.N., McCormack, M.C., Belli, A.J., Matsui, E.C., Peng, R.D., Aloe, C., Paulin, L. Williams, D.A.L., Diette, G.B., Breysse, P.N., 2013. In-home air pollution is linked to respiratory morbidity in former smokers with chronic obstructive pulmonary disease. Am. J. Respir. Crit. Care Med. 187, 1085-1090.

Hasday, J.D., Bascom, R., Costa, J.J., Fitzgerald, T., Dubin, W., 1999. Bacterial endotoxin is an active component of cigarette smoke. Chest 115, 829-835.

HCN., 2010. Endotoxins: Health-based Recommended Occupational Exposure Limit. Health Council of the Netherlands, The Hague, The Netherlands. Publication no. 2010/04OSH.

Heinrich, J., Gehring, U., Douwes, J., Koch, A., Fahlbusch, B., Bischof, W., 2001. Pets and vermin are associated with high endotoxin levels in house dust. Clin. Exp. Allergy 31, 1839-1845.

Heinrich, J., Pitz, M., Bischof, W., Krug, N., Borm, P., 2003. Endotoxin in fine (PM2.5) and coarse (PM2.5-10) particle mass of ambient aerosols. A temporo-spatial analysis. Atmos. Environ. 37, 3659-3667.

Holst, G., Høst, A., Doekes, G., Meyer, H.W., Madsen, A.M., Plesner, K.B., Sigsgaard, T. 2015a. Allergy and respiratory health effects of dampness and dampnessrelated agents in schools and homes: a cross-sectional study in Danish pupils. Indoor Air. http://dx.doi.org/10.1111/ina.12275.

Holst, G., Høst, A., Doekes, G., Meyer, H.W., Madsen, A.M., Sigsgaard, T., 2015b. Determinants of house dust, endotoxin, and $\beta-(1 \rightarrow 3)-D$-glucan in homes of Danish children. Indoor Air 25, 1-15.

Horick, N., Weller, E., Milton, D.K., Gold, D.R., Li, R., Spiegelman, D., 2006. Home endotoxin exposure and wheeze in infants: correction for bias due to exposure measurement error. Environ. Health Perspect. 114, 135-140.

Hwang, S.H., Park, D.J., Park, W.M., Park, D.U., Ahn, J.K., Yoon, C.S., 2016. Seasonal variation in airborne endotoxin levels in indoor environments with different micro-environmental factors in Seoul,South Korea. Environ. Res. 145, 101-108.

Jacobs, J.H., Krop, E.J., Wind, S.D., Spithoven, J., Heederik, D.J., 2012. Endotoxin levels in homes and classrooms of Dutch school children and respiratory health. Eur. Respir. J. 42, 313-322.

Jacobs, J.H., Krop, E.J., Borras-Santos, A., Zock, J.P., Taubel, M., Hyvarinnen, A. Pekkanen, J., Doekes, G., Heederik, D.J., 2014. Endotoxin levels in settled airborne dust in European schools: the HITEA school study. HITEA schools study consortium. Indoor Air 24, 148-157.

Johansson, E., Vesper, S., Levin, L., LeMasters, G., Grinshpun, S., Reponen, T., 2011 Streptomycetes in house dust: associations with housing characteristics and endotoxin. Indoor Air 21, 300-310.

Johansson, E., Reponen, T., Vesper, S., Levin, L., Lockey, J., Ryan, P., Bernstein, D.I., Villareal, M., Khurana Hershey, G.K., Schaffer, C., LeMasters, G., 2013. Microbial content of household dust associated with exhaled NO in asthmatic children. Environ. Int. 59, 141-147.

Kallawicha, K., Lung, S.-C.C., Chuang, Y.-C., Wu, C.-D., Chen, T.-H., Tsai, Y.-J. Chao, H.J., 2015. Spatiotemporal distributions and land-use regression models of ambient bacteria and endotoxins in the Greater Taipei Area. Aerosol. Air Qual. Res. 15, 1448-1459.

Kanchongkittiphon, W., Mendell, M., Gaffin, J.M., Wang, G., Phipatanakul, W., 2015 Review: indoor environmental exposures and exacerbation of asthma: an update to the 2000 review by the Institute of medicine. Environ. Health Perspect. $123,15$.

Larsson, L., Szponar, B., Pehrson, C., 2004. Tobacco smoking increases dramatically air concentrations of endotoxin. Indoor Air 14, 421-424.

Leung, T.F., Wong, Y.S., Chan, I.H.S., Yung, E., Wong, C.K., Lam, C.W.K., Wong, G.W.K., 2010. Indoor determinants of endotoxin and dust mite exposures in Hong Kong homes with asthmatic children. Int. Archives Allergy Immunol. 152, 279-287.

Liu, A.H., 2002. Endotoxin exposure in allergy and asthma: reconciling a paradox. J. Allergy Clin. Immunol. 109, 379-392.

Mazique, D., Diette, G.B., Breysse, P.N., Matsui, E.C., McCormack, M.C., CurtinBrosnar, J., Williams, D., Peng, R.D., Hansel, N.N., 2011. Predictors of airborne endotoxin concentrations in inner city homes. Environ. Res. 111, 614-617.

McNamara, M., Thornburg, J., Semmens, E., Ward, T., Noonan, C., 2013. Coarse particulate matter and airborne endotoxin within wood stove homes. Indoor Air 23, 498-505.

Menetrez, M.Y., Foarde, K.K., Ensor, D.S., 2001. An analytical method for the measurement of nonviable bioaerosols. J. Air \& Waste Manag. Assoc. 51, 1436-1442.

Menetrez, M.Y., Foarde, K.K., Esch, R.K., Schwartz, T.D., Dean, T.R., Hays, M.D. Cho, S.H., Betancourt, D.A., Moore, S.A., 2009. An evaluation of indoor and outdoor biological particulate matter. Atmos. Environ. 43, 5476-5483.

Michel, J., Kips, J., Duchateau, F., Vertongen, L., Robert, H., Collet, R., Pauwels, Sergysels, R., 1996. Severity of asthma is related to endotoxin in house dust. Am. J. Respir. Crit. Care Med. 154, 1641-1646.

Moniruzzaman, S., Engmanb, L.H., James, B., Sigsgaard, T., Thornee, P.S., Sundell, J. Bornehaga, C.-G., 2012. Levels of endotoxin in 390 Swedish homes: determinants and the risk for respiratory symptoms in children. Int. J. Environ. Health Res. 22.

Moon, K.W., Huh, E.H., Jeong, H.C., 2014. Seasonal evaluation of bioaerosols from indoor air of residential apartments within the metropolitan area in South Korea. Environ. Monit. Assess. 186, 2111-2120.

Morcos, M.M., Morcos, W.M., Ibrahim, M.A., Shaheen, M.A., 2011. Environmental exposure to endotoxin in rural and urban Egyptian school children and its relation to asthma and atopy. Minerva Pediatr. 63, 19-26.

Morgenstern, V., Carty, C.L., Gehring, U., Cyrys, J., Bischof, W., Heinrich, J., 2005. Lack of spatial variation of endotoxin in ambient particulate matter across a German metropolitan area. Atmos. Environ. 39, 6931-7641.

Mueller-Anneling, L., Avol, E., Peters, J.M., Thorne, P.S., 2004. Ambient endotoxin 
concentrations in PM10 from Southern California. Environ. Health Perspect. 112, $583-588$.

Norbäck, D., Markowicz, P., Cai, G.-H., Hashim, Z., Ali, F., Zheng, Y.-W., Lai, X.-X., Spangford, M.D., Larsson, L., Hashim, J.H., 2014. Endotoxin, ergosterol, fungal DNA and allergens in dust from schools in Johor Bahru, Malaysia- associations with asthma and respiratory infections in pupils. PLoS ONE 9.

Noss, I., Wouters, I.M., Visser, M., Heederik, D.J., Thorne, P.S., Brunekreef, B., Doekes, G., 2008. Evaluation of a low-cost electrostatic dust fall collector for indoor air endotoxin exposure assessment. Appl. Environ. Microbiol. 74 $5621-5627$.

Ownby, D.R., Peterson, E.L., Wegienka, G., Woodcroft, K.J., Nicholas, C., Zoratti, E., Johnson, C.C., 2013. Are cats and dogs the major source of endotoxin in homes? Indoor Air 23, 219-226.

Padhi, B.K.A., Adhikari, P., Satapathy, A.K., Patra, D.P., Chandel, P., 2016. Predictors and respiratory depositions of airborne endotoxin in homes using biomass fuels and LPG gas for cooking. J. Expo. Sci. Environ. Epidemiol. 1-6.

Park, J.H., Spiegelman, D.L., Burge, H.A., Gold, D.R., Chew, G.L., Milton, D.K., 2000. Longitudinal study of dust and airborne endotoxin in the home. Environ. Health Perspect. 108, 1023-1028.

Park, J.H., Gold, D.R., Spiegelman, D.L., Burge, H.A., Milton, D.K., 2001a. House dust endotoxin and wheeze in the first year of life. Am. J. Respir. Crit. Care Med. 163, $322-328$.

Park, J.H., Spiegelman, D.L., Gold, D.R., Burge, H.A., Milton, D.K., 2001b. Predictors of airborne endotoxin in the home. Environ. Health Perspect. 109, 859-864.

Park, J.H., Cox-Ganser, J., Rao, C., Kreiss, K., 2006. Fungal and endotoxin measurements in dust associated with respiratory symptoms in a water-damaged office building. Indoor Air 16, 192-203.

Pavilonis, B.T., Anthony, T.R., O'Shaughnessy, P.T., Humann, M.J., Merchant, J.A. Moore, G., Thorne, P.S., Weisel, C.P., Sanderson, W.T., 2013. Indoor and outdoor particulate matter and endotoxin concentrations in an intensely agricultural county. J. Expo. Sci. Environ. Epidemiol. 23, 299-305.

Perzanowski, M.S., Miller, R.L., Thorne, P.S., Barr, R.G., Divjan, A., Sheares, B.J., Garfinkel, R.S., Perera, F.P., Goldstein, I.F., Chew, G.L., 2006. Endotoxin in innercity homes: association with wheeze and eczema in early childhood. J. Allergy Clin. Immunol. 117, 1082-1089.

Rabinovitch, N., Liu, A.H., Zhang, L., Rodes, C.E., Foarde, K., Dutton, S.J., Murphy, J.R., Gelfand, E.W., 2005. Importance of the personal endotoxin cloud in school-age children with asthma. J. Allergy Clin. Immunol. 116, 1053-1057.

Rabinovitch, N.A., Liu, H., Zhang, L., Foarde, K., Rodes, C.E., Gelfand, E.W., 2006 Increased persona; respirable endotoxin exposure with furry pets. Allergy 61, 650-651.

Rao, C.Y., Riggs, M.A., Chew, G.L., Muilenberg, M.L., Thorne, P.S., Van Sickle, D., Dunn, K.H., Brown, C., 2007. Characterization of airborne molds, endotoxins, and Glucans in homes in new orleans after hurricanes katrina and rita. Appl. Environ. Microbiol. 73, 1630-1634.

Rennie, D.C., Lawson, J.A., Kirychuk, S.P., Paterson, C., Willson, P.J., Senthilselvan, A. 2008. Assessment of endotoxin levels in the home and current asthma and wheeze in school-age children. Indoor Air 18, 447-453.

Rennie, D.C.L.J.A., Senthilselvan, A., Willson, P.J., Dosman, J.A., 2012. Domestic endotoxin exposure and asthma in children: epidemiological studies. Front. Biosci. (Elite Ed. 1, 56-73.

Reponen, T., Singh, U., Schaffer, C., Vesper, S., Johansson, E., Adhikari, A., Grinshpun, S.A., Indugula, R., Ryan, P., Levin, L., LeMasters, G., 2010. Visually observed mold and moldy odor versus quantitatively measured microbial exposure in homes. Sci. Total Environ. 408, 5565-5574.

Reponen, T., Vesper, S., Levin, L., Johansson, E., Ryan, P., Burkle, J., Grinshpun, S.A., Zheng, S., Bernstein, D.I., Lockey, J., Villareal, M., Khurana Hersley, G.K., LeMasters, G., 2011. High environmental relative moldness index during infancy as a predictor of asthma at 7 years of age. Ann. Allergy, Asthma \& Immunol. 107, $120-126$.

Reponen, T., Lockey, J., Bernstein, D.I., Vesper, S.J., Levin, L., Zheng, S., 2012. Infant origins of childhood asthma associated with specific molds. J. Allergy Clin. Immunol. 130, 639-644.

Riggs, M.A., Rao, C.Y., Brownd, C.M., Van Sickle, D., Cummings, K.J., Dunn, K.H. Deddens, J.A., Ferdinands, J., Callahand, D., Moolenaar, R.L., Pinkerton, L.E., 2008. Resident cleanup activities, characteristics of flood-damaged homes and airborne microbial concentrations in New Orleans, Louisiana, October 2005. Environ. Res. 106, 401-409.

Rylander, R, 2002. Endotoxin in the environment-exposure and effects. J. Endotoxin Res. 8, 241-252.

Salonen, H., Duchaine, C., Letourneau, V., Mazaheri, M., Clifford, S., Morawska, L.
2013. Endotoxins in indoor air and settled dust in primary schools in a subtropical climate. Environ. Sci. Technol. 47, 9882-9890.

Samadi, S., Heederik, D.J., Krop, E.J., Jamshidifard, A.R., Willemse, T., Wouters, I.M. 2010. Allergen and endotoxin exposure in a companion animal hospital. Occup. Environ. Med. 67, 486-492.

Sebastian, A., Pehrson, C., Larsson, L., 2006. Elevated concentrations of endotoxin in indoor air due to cigarette smoking. J. Environ. Monit. 8, 519-522.

Semple, S., Devakumar, D., Fullerton, D.G., Thorne, P.S., Metwali, N., Costello, A., Gordon, S.B., Manandhar, D.S., Ayres, J.G., 2010. Airborne endotoxin concentrations in homes burning biomass fuel. Environ. Health Perspect. 118, 988-991.

Semple, S., Garden, C., Coggins, M., Galea, K.S., Whelan, P., Cowie, H., SanchezJimenez, A., Thorne, P.S., Hurley, J.F., Ayres, J.G., 2012. Contribution of solid fuel, gas combustion, or tobacco smoke to indoor air pollutant concentrations in Irish and Scottish homes. Indoor Air 22, 212-223.

Sheehan, W.J., Hoffman, E.B., Fu, C., Baxi, S.N., Bailey, A., King, E.-M., Chapman, M.D., Lane, J.P., Gaffin, J.M., Permaul, P., Gold, D.R., Phipatanakul, W., 2012. Endotoxin exposure in inner-city schools and homes of children with asthma. Ann. Allergy, Asthma \& Immunol. 108, 418-422.

Singh, U., Levin, L., Grinshpun, S.A., Schaffer, C., Adhikari, A., Reponen, T., 2011. Influence of home characteristics on airborne and dustborne endotoxin and $\beta-D-$ glucan. J. Environ. Monit. 13, 3246-3253.

Tager, I.B., Lurmann, F.W., Haight, T., Alcorn, S., Penfold, B., Hammond, K., 2010. Temporal and spatial patterns of ambient endotoxin concentrations in Fresno, California. Environ. Health Perspect. 118, 1490-1496.

Tavernier, G.O.G., Fletcher, G.D., Francis, H.C., Oldham, L.A., Fletcher, A.M., Blacklock, G., Steward, L., Gee, I., Watson, A., Frank, T.L., 2005. Endotoxin exposure in asthmatic children and matched healthy controls: result of IPEADAM study. Indoor Air 15, 25-32.

Tavernier, G., Fletcher, G., Gee, I., Watson, A., Blacklock, G., Francis, H., Fletcher, A., Frank, T., Frank, P., Pickering, C.A., 2006. IPEADAM study: indoor endotoxin exposure, family status, and some housing characteristics in English children. J. Allergy Clin. Immunol. 117, 656-662.

Thorn, J., Beijer, L., Jonsson, T., Rylander, R., 2002. Measurement strategies for the determination of airborne bacterial endotoxin in sewage treatment plants. Ann. Occup. Hyg. 46, 549-554.

Thorne, P.S., Kulhánková, K., Yin, M., Cohn, R., Arbes, S.J., Zeldin, D.C., 2005. Endotoxin exposure is a risk factor for asthma the national survey of endotoxin in United States housing. Am. J. Respir. Crit. Care Med. 172, 1371-1377.

Thorne, P.S., Cohn, R., Mav, D., Arbes, S.J., Zeldin, D.C., 2009. Predictors of endotoxin levels in U.S. housing. Environ. Health Perspect. 117, 763-771.

Thorne, P.S., Mendy, A., Metwali, N., Salo, P., Co, C., Jaramillo, R., Rose, K.M., Zeldin, D.C., 2015. Endotoxin exposure: predictors and prevalence of associated asthma outcomes in the United States. Am. J. Respir. Crit. Care Med. 192, $1287-1297$.

Todar, K., 2015. Bacterial endotoxin. Todar's Online Textbook of Bacteriology. Available online at. http://textbookofbacteriology.net/endotoxin.html.

Vedanthan, P.K., Mahesh, P.A., Vedanthan, R., Holla, A.D., Liu, A.H., 2006. Effect of animal contact and microbial exposures on the prevalence of atopy and asthma in urban vs rural children in India. Ann. Allergy, Asthma \& Immunol. 96, $571-578$.

von Mutius, E., Braun-Fahrlander, C., Schierl, R., Riedler, J., Ehlermann, S., Maisch, S., Waser, M., Nowak, D., 2000. Exposure to endotoxin or other bacterial components might protect against the development of atopy. Clin. Exp. Allergy 30, 1230-1234.

Waser, M., Schierl, R., von Mutius, E., Maisch, S., Carr, D., Riedler, J., Eder, W., Schreuer, M., Nowak, D., Braun-Fahrländer, C., 2004. Determinants of endotoxin levels in living environments of farmers children and their peers from rural areas. Clin. Exp. Allergy 34, 389-397.

Wheeler, A.J., Dobbin, N.A., Lyrette, N., Wallace, L., Foto, M., Mallick, R., Kearney, J., Van Ryswyk, K., Gilbert, N.L., Harrison, I., Rispler, K., Héroux, M.-E., 2011. Residential indoor and outdoor coarse particles and associated endotoxin exposures. Atmos. Environ, 45, 7064-7071.

Wickens, K., Douwes, J., Siebers, R., Fitzharris, P., Wouters, I., Doekes, G., 2003a. Predictors of endotoxin levels in carpets in New Zealand homes. Indoor Air 13, 128-135.

Wickens, K., Douwes, J., Siebers, R., Fitzharris, P., Wouters, I., Doekes, G., Mason, K., Hearfield, M., Cunningham, M., Crane, J., 2003b. Determinants of endotoxin levels in carpets in New Zealand homes. Indoor Air 13, 128-135.

Wouters, I.M., Douwes, J., Doekes, G., Thorne, P.S., Brunekreef, B., Heederik, D., 2000. Increased levels of markers of microbial exposure in homes with indoor storage of organic household waste. Appl. Environ. Microbiol. 66, 627-631. 